Article

\title{
Colorblind Islam: The Racial Hinges of Immigrant Muslims in the United States
}

\author{
Jeffrey Guhin \\ Department of Sociology, University of California Los Angeles, Los Angeles, CA 90095-1551, USA; E-Mail: guhin@soc.ucla.edu
}

Submitted: 14 February 2018 | Accepted: 18 May 2018 | Published: 22 June 2018

\begin{abstract}
Islam is increasingly theorized as a "racialized" category in the United States, yet these accounts can too often emphasize a top-down approach of racial identification and obfuscate the importance of the African-American Muslim experience. Using Maghbouleh's (2017) concept of "racial hinges", the author synthesizes previous work and provides evidence from his own ethnographic research to describe how immigrant Muslims in the United States leverage different racial "strategies of action" (Swidler, 1986), including white acculturation and black appropriation. In the conclusion, the author suggests a third strategy: brown solidarity.
\end{abstract}

\section{Keywords}

complex religion; ethnicity; immigration; Islam; race

Issue

This article is part of the issue "Complex Religion: Intersections of Religion and Inequality", edited by Melissa J. Wilde (University of Pennsylvania, USA).

(C) 2018 by the author; licensee Cogitatio (Lisbon, Portugal). This article is licensed under a Creative Commons Attribution 4.0 International License (CC BY).

\section{Introduction}

It is increasingly common to theorize the "racialization" of American Muslims (Bayoumi, 2015; Cainkar, 2009; Carr \& Haynes, 2015; Galonnier, 2015; Garner \& Selod, 2015; Ibrahim, 2008; Selod, 2015; Selod \& Embrick, 2013). Yet theories of the racialization of American Muslims can often run into two problems. First, these arguments tend not to refer to all American Muslims, which are a diverse and heterogeneous category (GhaneaBassiri, 2010; Hussain, 2016), but rather to immigrant Muslims. Second, these theories also emphasize a top-down process of racialization, occluding the ways that immigrant Muslims are able to leverage certain kinds of racial ambiguity. This article builds upon Neda Maghbouleh's (2017) concept of "racial hinges" to describe how immigrant Muslims in the United States deal with these ambiguities, navigating their relationships among Muslims ethnicities and with African Americans and whites. In doing so, I build on Melissa Wilde's concept of "complex religion" (Wilde, 2017; Wilde \& Glassman, 2016; Wilde \& Tevington, 2017) to argue that American Islam is only sociologically intelligible through its intersections with other salient identities especially, for the purposes of this article, race and ethnicity. Taking Wilde's challenge to render more complex our understandings of religion, I argue that not only should scholars acknowledge how Islam in America is racialized but they should also show the complicated ways in which immigration and ethnicity intersect with these racialization processes.

In her study of Iranian Americans-many though not all of whom are Muslim-Maghbouleh gets right at this complexity, describing "racial hinges" as the processes through which racial liminality "opens or closes the door to whiteness as necessary" (Maghbouleh, 2017, p. 5). In describing these hinges, Maghbouleh demonstrates how, "for liminal racial groups, whiteness is fickle and volatile" even for those, like Iranians and other immigrants from the Middle East, who are considered "white" by United States law and might consider themselves white as well (Maghbouleh, 2017, p. 13). The state and broader cultural processes are important here, but analysis of these processes can too often be exclusively topdown (Maghbouleh, 2017, p. 170).

Maghbouleh shows how the racial experience of immigrant Muslims is not only about the security state 
and media representations depicting Muslims as racialized others (Jamal, 2008), developing the term "racial hinge" to describe how Iranian Americans can manipulate (or at least attempt to manipulate) their ambiguous relationship to whiteness. As such, Maghbouleh's study of racial hinges and racial loopholes helps her to understand how Iranian Americans navigate "the limits of whiteness" and also the capacity to "forge new racial identities...becoming brown by choice and by force" (Maghbouleh, 2017, p. 172). In this article, I expand upon the concept to describe how immigrant American Muslims can manipulate their relationship to whiteness and black identity. It is important to acknowledge that such agentic possibilities are not necessarily normatively positive ones, and greater racial freedom can sometimes lead to more capacity to leverage strategies of racial domination.

By describing Muslims as at once racialized and capable of creative manipulation of racial categories, I challenge an "analytical groupism" (Brubaker, Loveman, \& Stamatov, 2004, p. 31) that can sometimes occur in studies of racialized Islam. Analytical groupism refers to a tendency among both laypeople and academics to take groups for granted as the most appropriate way to understand the world, an insight somewhat paralleled by Wilde's concept of "complex religion". The concept of American Muslim "racialization" can sometimes fall into this groupist tendency, especially when assuming that immigrant Muslims' top-down racialized category is the most salient means through which to understand them. As will be discussed below, this is not to deny that immigrant Muslims are racialized or that such a category is both politically and empirically important. It is simply to say that immigrant Muslims' relationship to race is more complex than their racialization by the security state and popular culture, and that it is also a relationship marked by agentic manipulation of various racial strategies of action. Race, like any social category, is always a social accomplishment, and immigrant Muslims have access to various, contextually motivated "strategies of action" (Swidler, 1986) through which to enact those accomplishments; they are able to do so in a way that African American Muslims are not.

To be clear, immigrant Muslims' access to a variety of often contradictory racial and ethnic discourses is by no means a net advantage: indeed, it is often the result of white supremacy, decades of colonial intervention in immigrants' countries of origin, and both explicit and implicit bias. Institutionalized Islamophobia (Kundnani, 2014) compels Muslims to perform a "good Muslim" status (Mamdani, 2005) even for those potential "liberal" allies who claim to be religiously neutral. Yet, because of many immigrant Muslims' status as "brown" (Silva, 2010, 2016) rather than "black" in the United States racial order (Emirbayer \& Desmond, 2015), as well as their potential ability to shift between ethnic, racial, and religious registers (in a way that African Americans cannot), immigrant Muslims are able to engage political and cul- tural problems through often contradictory approaches to race, ethnicity, and religion. To be clear, to say Muslim Americans are "brown" is not necessarily to argue many of them self-identify as brown; it is simply to argue that, as Silva, Maghbouleh and other theorists of the "brown" identity have postulated, to be "brown" gives immigrant Muslims a racial (and not simply ethnic) identity that is nonetheless outside of the typical black/white binary.

For the purposes of this article, I describe "immigrant Muslims" as those 76\% of American Muslims who are either immigrants or children of immigrants (Pew, 2017). Histories of American Islam (e.g., GhaneaBassiri, 2010; Husain 2017) often situate such immigrant Muslimsmany of whom came after changes in U.S. immigration law in 1965-as separate from indigenous American Islam, which is predominantly composed of black Muslims who have been in the United States much longer. According to Pew (2017), 20\% of Muslim American adults selfidentify as black, of whom only $11 \%$ are foreign born. Of those black Muslims born in the United States, over half have families that have been in the United States for at least three generations (Pew, 2017).

In what follows, I will provide a brief methods section, a literature review of debates about the best way to categorize Islam in the United States, and finally, a theoretical synthesis that combines some of my own empirical work with other research on American Islam. I provide two examples of immigrant Muslims' racial strategies of action: (1) white/colorblind acculturation, and (2) black appropriation, suggesting in the conclusion that brown solidarity could also be an important third form.

\section{Methods}

This article is primarily a theoretical synthesis of earlier secondary literature, reframing previous work on the racialization of Islam. However, to further develop my argument, I also draw from fieldwork at one of the schools I studied as part of a broader comparative ethnographic study of two Sunni Muslim and two Evangelical Christian high schools. I spent a semester and a half at Al Amal high school, a Muslim K-12 school in the New York City area. There were about 200 students total in the school, and most of the student body was Arab and South Asian, with some students of African ancestry. In the calendar year of 2011, I spent around two days a week at Al Amal, observing classes, teaching an SAT class, and talking to community members. I will be vague about some numbers and identifying characteristics to preserve confidentiality, and I have used pseudonyms for people and the school itself.

\section{Islam Between Religion and Racialization}

\subsection{What Kind of Category is Islam?}

Many social scientists have recently begun to describe Islam in manners similar to how one would describe a race 
or ethnicity (Motyl, 2011). They echo a tendency in both laypeople's "categories of practice" and social scientists' "categories of analysis" in considering religion as functionally (if not substantially) similar to other categories of difference, such as ethnicity, language, race, and region of origin (Brubaker, 2013, pp. 4-5). As Rogers Brubaker describes, the journal Ethnic and Racial Studies published only 15 articles on religion before 1990 and, between that time and the publication of his article in early 2013, it had 88 articles on religion, $50 \%$ of which were about Islam (Brubaker, 2013, p. 2). Yet simply because Islam is being studied as a category with parallels to race does not necessarily mean Islam is racialized. What makes Islam racialized, rather, is the way that it takes on characteristics often used to describe races, both via more commonly studied top-down racialization processes (media, government) and less studied bottom-up processes in which immigrant Muslims themselves take advantage of "racial hinges" to navigate ambiguous racial situations.

Questions about Islam and race must therefore center how Islam is both presented and experienced as a category, and an important insight of studies of black Islam as compared to immigrant Islam is that this category is both presented and experienced in radically distinct ways for different groups of American Muslims (Grewal, 2013; Karim, 2008; Khabeer, 2016). As such, questions about the relationship between race and immigrant Islam are necessarily related to (though still separate from) questions about the relationship between immigrant and African American Muslims and the experience of ethnicities often associated with Islam, such as Arabs and South Asians (Love, 2017). While I will further discuss the analytic challenge of African American Muslims for accounts of Muslim racialization below, it is worth examining here the relationship between ethnicities often associated with Islam (such as Arabs) and Islam as itself a racialized category.

Accounts of what it means to be Arab in America narrate a "model minority" status that was cut short by international events, "a general proximity to whiteness and a sense of acceptance within white middle-class America up until the late 1980s and early 1990s, the period in which the United States was consolidating its growing imperial interests in the Middle East and North Africa" (Naber, 2012, p. 26). In Jamal and Naber's 2008 edited volume, Race and Arab Americans before and after 9/11, various scholars describe how the experience of Arabs after 2001 has been a particularly difficult one (see also Bayoumi, 2009, 2015; Cainkar, 2009; Peek, 2011), though that difficulty is inexplicable without acknowledging the link between being Arab and being Muslim. Indeed, despite the volume being a book about Arab Americans, the phrases "Arabs and Muslims" or "Muslims and Arabs" show up 19 times, and in six of the 12 chapters.

Such a linkage is not necessarily because Arabs are Muslim (only 25\% of Arab Americans are Muslim) or because American Muslims are Arab; the numbers are more difficult to determine here, but Pew says $41 \%$ of Ameri- can Muslims identify as white, which would include Arab, Persian, and "Middle Eastern" identities (Pew, 2017). Rather, it is because anyone perceived as "brown" can sometimes be assumed to be Muslim and, therefore, a threat of Islamist terrorism (Silva, 2016), a finding consistently discovered in work on both Muslim Americans and those assumed to be Muslim Americans (Bayoumi, 2009; Mahalingam, 2012). For example, in his interviews with Egyptian Americans, Zopf (2017) found that even his respondents who identified as white were often not recognized as white by other Americans, a finding paralleled by Maghbouleh in her study of Iranian Americans.

Yet the fact that many Arab Americans are not Muslim provides a window into the relationship between race and Islam in the United States. In her study of racial and ethnic identity among Muslim and Christian Arabs in central Texas, Read (2008) found that "one-third of Christian respondents report that other people consider them 'white', compared to only 5.2\% of Muslims". She goes on that only "a small fraction" of Muslims feel "they pass as 'white' Americans" (Read, 2008, pp. 312-313). In this case, the term Arab American is understood as a racial rather than an ethic category in that it is seen as oppositional to rather than potentially coexistent with being white. I found this in my own work as well. At Al Amal, I met a blonde Palestinian-American Muslim teacher, Dafir, who said he enjoyed surprising "white people" when they found out he was an Arab. I asked him if he considered himself white. "No", he said proudly, "I'm Arab".

For Dafir, as well as for many of Read's (and Maghbouleh's) respondents, Arab or Iranian are racial categories and not simply ethnic ones. Furthermore, this Arab racial category seems to be tied to Islam, meaning that it is not just culture but a kind of religious culture-rather than simply phenotype-that can racialize. Of course, to argue that race is much more than skin color is a very old insight in the sociology of race ( $\mathrm{Du}$ Bois, 2015; Omi \& Winant, 2014), but it is helpful to make sense of how a religion like Islam can become racialized.

It was striking to me how often Dafir and others at $\mathrm{Al}$ Amal (both teachers and students) conflated to be Arab and to be Muslim, which I would later learn is a common criticism from both non-Arab immigrant Muslims and African American Muslims (Bilici, 2012; Jackson, 2005). This tendency to conflate Arab and Muslim can happen among the broader, non-Muslim public as well. Bayoumi describes his 2009 book, How does it feel to be a problem?, as mostly a study of Muslims Arabs, yet he nonetheless acknowledges throughout the ways that being Arab and being Muslim are racialized, and in similar ways relative to the whims of a broader security apparatus.

Similarly, Cainkar's 2009 book, Homeland insecurity, is subtitled: "The Arab American and Muslim American Experience After 9/11". Cainkar argues that Arab identity has become racialized to the degree that Arabs are seen as having certain traits (e.g., violent, hateful) that are biological and essential: 
When similar social constructions about an inherent tendency to violence were nearly seamlessly extended to Muslims, Arabs and Muslims came to be viewed by many Americans in an undifferentiated way...that was associated with a certain phenotype, mode of dress, written script, type of name, set of religious beliefs and attitudes towards women, and specific countries of origin. (Cainkar, 2009, p. 109)

Bayoumi likewise argues that "Arabs and Muslims" are "two overlapping categories, but in the world of American perceptions [they are] essentially the same thing" (Bayoumi, 2009, p. 190). These are racial theories because they are about categories understood to be essential and unalterable.

Those "American perceptions" to which Bayoumi refers are a longstanding habit of Islamophobia and the essentialization of Muslims as fundamentally dangerous and violent in entertainment and news media (Bail, 2014; Hussain, 2010; Marzouki, 2017; Saeed, 2007) as well as in government discourse and policy decisions (Cainkar, 2009; Peek, 2011). Cainkar describes how special registration programs "give concrete meaning to essentialized, undifferentiated representations of Arabs and Muslims" (Cainkar, 2009, p. 58). Likewise, Bayoumi describes how "through special registration [of Muslims], the [United States] government, in effect, turned a religion, namely Islam, into a race" (Bayoumi, 2015, p. 51). Special registration programs required "adult males from twenty-four Muslim-majority countries...to register their whereabouts in the country" (Bayoumi, 2015, p. 186), thereby leveraging state power to maintain an overriding suspicion of Muslims as essentially violent and worthy of suspicion.

Yet to say that Islam is racialized is not quite the same as to say that Islam is a race. As Morning (2009) defines it, race does not refer to any biological reality, but rather to a sociological grouping of certain individuals believed to share a common genealogical descent marked by certain shared phenotypical traits. Morning thereby distinguishes race from ethnicity, which, in the American context, is viewed as optional and symbolic, capable of being chosen and rejected, "with the knowledge that such identification will have little if any repercussions for major life outcomes" (Morning, 2008, p. 242; see also Gans, 1979; Waters, 2001). In contrast, "racial identity is usually portrayed as involuntary-it is imposed by others-and it is immutable, regardless of individual behavioral choices....This externally enforced affiliation has profound and far-reaching effects on life outcomes" (Morning, 2008, p. 242). As Morning finds regarding South Asian racial self-identifications (Morning, 2001), racial identity is often a function of other socioeconomic factors rather than simply reproducing parents' identity, a process demonstrated even in reference to the seemingly intractable black-white binary (Roth, 2005; Saperstein \& Penner, 2012). Islam is complicated here: it fits the elements of Morning's definition that list race as involuntary, immutable, and having real effects on the life course-at least in terms of how Islam is often perceived. Yet Islam is not-at least it is usually notconsidered a part of an immutable biology. The use of the term racialized seems a helpful middle way, showing how Islam might not be a race but that the experience of Islam in the United States has various parallels with racial categories.

Yet there are some important complications to the work described above. First, and perhaps most importantly, the description of Muslims as racialized tends to emphasize post-1965 "immigrant" Islam over indigenous Islam, which is generally African-American. To be clear, none of the authors mentioned above ignores African American Islam: both Cainkar and Bayoumi, for example, are careful to acknowledge the critical role of African Americans in Muslim American history and the complicated relationship between immigrant Muslims and African-American Muslims in the United States. Yet because much of their focus is on Arab experiences of marginalization, their emphasis tends to be on the experiences of "immigrant" Muslims rather than on other groups.

The second complication follows from the first. In describing the processes of "racialization" Muslim Americans experience, these authors identify the source of racial identification outside of the Muslims themselves, generally in cultural processes (popular discourse, news, entertainment media) and state policies (immigration laws, special registration). To the extent the authors talk about how people navigate their racial identity themselves, it is generally as a means of explaining what it means to be Arab or an Arab Muslim rather than what it means to be Muslim more generically, or even simply an immigrant Muslim, at least within a racial context.

\subsection{How a Racialized Religion Fits into the Ethnic Paradigm}

Definitions of Islam often understand it as a religion: Esposito's (2016) standard textbook calls Islam one of the world's religions in the very first page of the introduction. Yet it not as obvious as it might appear what is religious and what is not. In fact, the deconstruction of the category of religion has been an important conversation within religious studies (Masuzawa, 2005), anthropology (Asad, 1993), and sociology (Guhin, 2014), all of them suggesting that calling something religious is just as much a political and normative movement of power as it is a description of a certain element of social life. Nonetheless, today in the United States, even if some conservative Christians describe Islam as unworthy of the category of religion, it is generally the case that Islam is considered a religion, at least in so far as mosques are given the tax-exemptions provided to churches and Muslims are ensured (though not always ensured) certain religious privileges in state institutions that parallel other religious privileges. 
Yet Islam, it seems, is more than just a religion. That Islam works as a category relatively separate from (though perhaps replaceable for) someone's ethnicity is sociologically relevant, as it can describe various social processes, including how second generation Muslim immigrants develop strategies of negotiation for engaging their parents' ethnic identity. In Naber's (2005) study of second generation Arab-American Muslims, she shows how an "ideological framework" of "Muslim first/Arab second" allows her respondents to form an identity category that gives them space to negotiate cultural and gender expectations with immigrant parents. Furthermore, her "research participants tended to argue that 'while Arab culture is based on racism, Islam is based on racial equality"” (Naber, 2005, p. 490). There are two important pieces here: first, that "Muslim" is even capable of replacing a category like Arab implies that "Muslim" is coming to function as an ethno-racial category, and second, as will be described in more detail below, the "colorblindness" of Islam can be used to obfuscate and reify a kind of immigrant Muslim privilege (Naber, 2005, p. 491).

Naber is not the only one to describe how secondgeneration immigrant Muslims are forming a "Muslimfirst, ethnicity-second" ideological commitment. "America's Muslim student movement", Abdo (2006) writes:

$[\mathrm{H}]$ as gone a long way toward creating a multicultural Islam among second-generation Muslims. Students from diverse ethnic backgrounds join the Muslim Students' Association and encounter, often for the first time, Muslims outside their own ethnic groups. (Abdo, 2006, p. 196).

Bilici (2012) also describes how many second-generation American Muslims prize the American Muslim community for the opportunity it provides to live a "free" Islam unfettered by the constraining and often conservative cultures in majority Muslim countries, and, sometimes, from immigrant parents. Such a commitment to a Muslim-first, ethnicity second ideology seems counterintuitive given how many mosques have one dominant ethnicity (Bagby, 2012; Karim, 2008). Yet Muslims are more than their mosques, and high schools (like the ones I studied), Muslim Students' Associations, and other forms of Muslim cultural work provide opportunities to create an American ummah (Arabic for community of all Muslims) not necessarily linked to any one ethnicity. In his account of American Islam, Bilici (2012) shows how cultural and political expressions ranging from Muslim stand-up comedy to Muslim political activism provide opportunities to create a different kind of emergent American Muslim identity, one not necessarily tethered to ethnic origins.

I also found this second-generation Islam-first commitment in my own work. A South Asian female student at Al Amal, Sara, complained to me that the school was more ethnically conscious than her previous one, which she described as more "Muslim": "Here it's more of a cul- ture", she told me:

There's a lot of Arabs here and over there it was so mixed, it was mostly children of converts, so people weren't always asking where are you from. Like when I got here, people would always ask me where are you from? And I was like, Um, New York?

Sara wants to be simply a Muslim from New York, in the way that many second-generation Muslims emphasize their Islam over their cultural backgrounds. Indeed, many second-generation Muslims told me how their parents' Islam was more "culture" than "religion": as Bilici describes, it's in America that Islam can be truly pure. As described above, there is a liminal kind of freedom in Sara's recognition that an Islam beyond ethnic or racial identity is possible, and it presents various strategies of action, some of them "racial hinges" towards either a colorblind ideology of racial indifference or, potentially, the kind of "brown" solidarity I will discuss in the conclusion, a solidarity that both extends beyond but still recognizes ethnic and racial identities and marginalizations. Yet all of this moves a bit beyond what Sara wanted, which was simply to have the freedom to be a New York Muslim without any ethnicity necessarily attached to it. Yet this is a racial hinge as well, given how hard it would be for a black Muslims to ever stop being seen as black (Jackson, 2005, 2009).

Sara's desire for an integration into a broader "Muslim" identity category is theoretically important for another reason: it challenges contemporary theories of ethnic assimilation. Debates about segmented assimilation (Zhou, 1997) often focus on Latin American and East Asian immigrants and to which segment of the society they will assimilate, usually not describing the role of religion in those processes (see Warner, 2007). Except for certain conservative critiques (Huntington, 2004), there is much less concern about Latin American religion, which is usually Catholic or Protestant. Similarly, except for concern about Islam, South Asian and East Asian religions are usually not considered especially important either (Warner, 2007), except perhaps as a means of connecting to the country of origin rather than as a means of non-national or non-ethnic solidarity, as was once the fear with Catholics and Jews and is now the fear about Muslims. As such, the middle way of "selective acculturation" does not quite capture the experience of second generation Muslim Americans to the extent they seek the kind of Muslim second generation described above. In Portes and Rumbaut's (2016) telling, selective acculturation "means the acquisition of English fluency and American cultural ways along with preservation of certain key elements of the immigrant culture, of which language is paramount" (Portes \& Rumbaut, 2016, p. 350, italics in original). Yet for many second generation American Muslims, to the extent that language matters, is not necessarily the language of their parents, but Arabic, the language of the Qur'an. For example, Grewal (2013) 
shows how a variety of second generation Muslims and Muslim converts travel to the Middle East partially for religious instruction, but also to learn the sacred language of Islam. Similarly, in Muslim Students' Associations and Muslim organizations across the country, there is a normative commitment to gaining fluency in Arabic for the most devout of Muslims, and many learn at least a few Arabic phrases to better describe religious ideas and commitments (prayer becomes salah, religion becomes din, etc.) Additionally, the very devout might seek to memorize the Qur'an in Arabic (becoming a hafiz or hafiza), a vital goal for many Muslims around the world, especially young people.

Both Islam and the language (but not the ethnicity) of Arabic become important common sources of identity for second-generation immigrants from various countries, a kind of selective acculturation distinct from those usually examined by sociologists of immigration. As a result, immigrant Muslims again gain access to a kind of racial liminality in that they are able to claim that their religious identity supersedes either ethnic or racial identity. Contemporary Islamophobia might make such a claim more or less difficult, but even the possibility of making it manifests a kind of racial hinge often unavailable to black Muslims, who are much less able to find an identity that supersedes race. The desire for an American ummah, therefore, runs the risk of forming a kind of "colorblind Islam". However, this is not to be cynical: it is entirely possible to create an American ummah that is still sensitive to racial inequality, as I will describe in the next section.

\section{Immigrant Muslims' Racial Strategies of Action}

In their study of white Evangelicals' racial attitudes and behaviors, Emerson and Smith (2000) import Swidler's (1986) concept of the cultural toolkit to explain the specific "strategies of action" that white Christians use to engage problems of racial inequality. My use of the toolkit concept here is slightly different and has more in common with studies of race as an ongoing social accomplishment rather than a taken-for-granted social fact (Brubaker, 2016, p. 145; Emirbayer \& Desmond, 2015; Roth, 2012, pp. 151-175). This is not to deny that race is a powerful social construct in American life with real weight on people's lives regardless of their particular social performances. As described above, the racialization of American Islam has serious material and symbolic effects.

However, it remains important to recognize that race, like any other identity, is also a social accomplishment, one which requires the participation of various interactants. People are socialized into particular scripts regarding how race and ethnicity are to be understood as appropriately authentic or inauthentic (Lu \& Fine, 1995) and they allow for certain performances while not allowing other, at once creating and maintaining "sumptuary codes" that "enforce social classification...consist[ing] of rules, written or unwritten, that establish unequal rank and make it immediately visible" (Fields \& Fields, 2012, p. 33). Such codes are most clear in the United States regarding the relationship between whites and African Americans, making the situations of "brown" Americans interstitially complex, especially for those who are immigrants or the children of immigrants (Sanchez \& Romero, 2010). Maghbouleh's (2017) concept of the racial hinge helps to show how liminal positions within identity categories allow for a greater breadth of social accomplishments. Based on my own fieldwork and on the other work on American Muslims to which I refer in this article, I describe two such strategies: white/colorblind acculturation and black appropriation, suggesting in the conclusion that brown solidarity might be a third.

\subsection{White/Colorblind Acculturation}

Al Amal's senior graduation ceremony was conducted offsite in a large ballroom a few miles from the school, with 40 or so seniors all sitting in robes in the front row, their families gathered behind them. The commencement speaker, a professor from a nearby university, urged the graduates and their families: "As Muslim Americans, we have to represent ourselves....we have to do what the Italians, Irish, and African-Americans all did before us, we have to challenge those stereotypes...for some people when you say Muslim, it means terrorist, and we have to challenge this". Note how the speaker conflates race, ethnicity, and religion, all at once, providing a narrative of progress through which Muslims-whatever they arewill eventually become American. Note as well how the struggles of African Americans are narrated in the past tense and in parallel with the integration efforts of white ethnics, thereby no longer requiring present solidarity, a move paralleled by many white Americans. Immigrant Muslims' use of racial hinges is clear here: in this reading, whites' racial distinction of Muslims as "other" is a door immigrant Muslims can move through, something they can turn with effort and work (even if they run the risk of the door being turned back upon them by people assuming they are terrorists).

While 9/11 challenged American Muslims' attempts at full assimilation, it is by no means a lost goal. As the above quote demonstrates, many Muslim immigrants seek to assimilate broadly with the rest of the United States. That does not necessarily mean they want to become white as much as it means that they want to become American (Bilici, 2012), viewing American identity as something that can be, with some effort, reconciled with the Muslim faith. Of course, it remains an open question whether such American aspirations are necessarily white. Both Muslim schools I studied seemed well described by Portes, Fernandez-Kelly and Haller's (2005) description of immigrants' aspirations towards "the enviable lifestyles of the mostly white upper middle class" (Portes, Fernandez-Kelly, \& Haller's, 2005, p. 1004), yet the whiteness of this middle class might be an incidental 
rather than an essential characteristic. The real challenge is proving the degree to which they are a part of America.

As Grewal (2013) describes, this need to defend Americanness is not a problem for indigenous black Muslims, who are clearly American, even if America's racial codes assign them a secondary social status. African Americans have the "social citizenship" Muslim immigrant communities lack, and these communities hope they can gain that citizenship while being able to enjoy racial privileges African Americans cannot (Grewal, 2013, pp. 10-11). But does gaining such social citizenship require acknowledging the problem of cross-racial solidarity? In my fieldwork and in some of the studies described here, certain immigrant Muslims seek an American identity that is not necessarily white but is certainly colorblind, that is, able to "see past" race. These immigrant Muslims with a colorblind ideology (Bonilla-Silva, 2006) resent the ways that their identities are racialized and marked as different. The colorblind ideology, according to Manning, Hartmann, and Gerteis (2015), consists of three "core dimensions": abstract liberalism, minimization of racism, and cultural racism. That emphasis on colorblindness is a common theme across the global ummah (or community of Muslims), and, as noted by Naber $(2005,2012)$ above, it is sometimes an accompaniment to an ideological commitment to putting "Muslim" before an ethnic identity. Muslims cannot be racists, the idea goes, because all Muslims are united in their faith. To the extent American Muslim immigrants want to transcend race-including their own racial identities-it can also mean they obfuscate or ignore the racial politics that affect other Americans, including black Muslims.

That commitment to a colorblind ideology showed up regularly at Al Amal while I was there, and it can be found in a variety of immigrant Muslim organizations in the United States. As the Al Amal vice principal told me once while we were chatting about school discipline: "When you look at this school...look at their skin colors. They have different ethnicities, different languages, different culture and backgrounds. And they know that I will not judge them based on this, they will not be judged by their face or background. They will be judged by their deeds". In the assistant principal's comment, we see at least two of the three characteristics of colorblindness: a focus on abstract liberalism (equal procedures that treat each individual autonomously) and a minimization of racism. This focus on colorblindness therefore reifies a kind of whiteness, so even if it does not necessarily encourage a "whitening" of immigrant Muslims, it does hold open the possibility of immigrant Muslim white privilege. Even if those immigrant Muslims may not identify as white, and even if they are not able to leverage a colorblind ideology in the face of a security state and popular media that racializes them, the argument that race does not matter seeks a movement towards a kind of Muslim white privilege, or at least a Muslim ethnicity in which racial identity is able to be looked past because it is no longer recognized as essential, a "racial hinge" un- available for African Americans (Bonilla-Silva, 2006; Omi \& Winant, 2014).

This focus on colorblindness (and potential white aspiration) extends across the American Muslim sphere. In her dissertation on Zatyuna College, the first Muslim institution of higher education in the United States, Maryam Kashani (2014) shows how the faculty and student body of Zaytuna-the majority from immigrant Muslim families-often attempt to see past this colorblindness, ensuring that African American Islam is recognized as an important elements of American Islam and describing the hard challenges of structural racism as experienced by (and sometimes maintained by) American Muslims (Beydoun, 2018). The university was founded by a white convert, an African American convert, and a Palestinian American (Kashani, 2014, p. 12), and its lesson plans often seek to acknowledge and reconcile real racial differences in American Islam, rather than simply papering them over as so many different colors of skin in the mosque. Yet such work is noteworthy precisely because it is not necessarily common. Indeed, the popularity of the white convert founder Hamza Yusuf (and the growing success of other white converts) can be interpreted as an implicit wish for cultural assimilation, as Kashani (2014) describes: "As a symbolic figure for a type of American Islam, Yusuf embodied the possibilities for other Muslims to assimilate, whether they were from Pakistan, Syria, Indonesia, or Afghanistan...signify[ing] aspirations of whiteness and cultural citizenship in an American landscape of racial inequality and subjugation" (Kashani, 2014, pp. 114-115; see also Grewal, 2013, pp. 159-169, 305-313; Tourage, 2013). A secondgeneration effort to create an "American Islam" that moves beyond ethnic differences between Muslim immigrant groups can, ironically, reproduce a white colorblind ideology through ignoring or at least downplaying what Sherman Jackson (2009) calls "the problem of black suffering". To be clear, this is not to argue that all immigrant Muslims seek such a colorblind ideology or that an American ummah is necessarily colorblind. Indeed, the key argument of this article is that immigrant Muslims' racial hinges give them access to a variety of racial strategies of action, and the degree to which these are used by any one individual or group-as well as how often they are used-are separate empirical questions.

\subsection{Black Appropriation}

American Muslims go back to the country's precolonial roots, with African slaves keeping their Muslim heritage as best they could despite slave-owners' attempts to strip them of their pasts (GhaneaBassiri, 2010; Hussain, 2016). Black communities were instrumental in the development of various forms of American Islam (Grewal, 2013, pp. 79-124), forms which have been in an uneasy tension with the growing number of immigrant Muslims in the United States since changes in immigration laws in 1965 (Jackson, 2005, pp. 131-169). One reason for this 
tension is the question of whether the uneasy solidarity between African-American Muslims and immigrant Muslim can overcome racial inequalities, as well as some immigrants' support for (or at least silence regarding) the white supremacy that keeps those inequalities alive.

In my time at Al Amal, I regularly heard an Arab boy, a junior, use the n-word with other students. I asked him once if he knew any black people, and he said no. He was a brown-skinned Arab, one of many at Al Amal who, like many in America, loves hip hop music and identifies with certain elements of black culture, especially a key element of much of the male student experience at Al Amal: basketball (O'Brien, 2017; see also Warikoo, 2011). Blackness, for these students, was associated with pleasure, and they felt, as do white people in a colorblind society (Rodriquez, 2006), that they could sample that pleasure without any moral problem or obligation. Blackness, for them, was also associated with African American identity (which was not represented at their school) rather than simple phenotype. I accompanied some boys to the school's storage area, where they had to clean out some boxes of textbooks. They were looking at old pictures of students and saw an African-American student. "Remember him?" asks one. Another said: "Oh yeah, he was black, so we were all like, 'yo, can you play [basketball]?' and he was like, 'yeah I can play' and then we saw him playing and like, he was terrible!" They all laughed. "We were like, 'finally, a black guy, and he can't even play basketball!"' They laughed again. Apparently, they did not make assumptions about the black students from Egypt and sub-Saharan African then at the school.

Like many American whites, these immigrant Muslims felt they could appropriate black culture in their own experience, even judging the qualities of African American Muslims based on how they lived up to certain racialized expectations. Yet immigrant Muslim appropriation is not quite the same as white appropriation: as I have described above, immigrant Muslims are also racialized, and are sometimes referred to as "the new blacks" (Bayoumi, 2015, pp. 185-209). Yet such solidarity is not necessarily equally shared, and there are ways that black and Latino Muslims, for example, can feel as though immigrant Muslims can use their experience of racialized marginalization as a pass for the ability to appropriate black culture (Khabeer, 2016). This is another racial strategy of action at least potentially available to American immigrant Muslims, a "racial hinge" through which they can experiment with black identity in a way seemingly unavailable to whites.

Khabeer's (2016) book, Muslim cool: Race, religion, and hip hop in the United States, analyzes the role of black culture in developing a kind of "Muslim Cool", allowing for cross-ethnic solidarities and artistic creation in the service of anti-racism. Yet too often, she argues, immigrant Muslims love black culture but not black people, appropriating and instrumentalizing black traditions without recognizing the centrality of the black experience to broader Islamic history and to contemporary
American Islam (see also Jackson, 2005; Rouse, 2004). Khabeer's broader argument is an insistence that such appropriation is not the only way in which immigrant Muslims can approach native black Muslims and black culture (see also O'Brien, 2017). Indeed, "Muslim cool" is, for Khabeer, both an aesthetic and normative goal of cross-racial solidarity within the ummah.

Yet to the extent that immigrant Muslims' relationship to African Americans is one of appropriation rather than solidarity, it is because of the colorblind ideology described above, a sense in which black culture can be at once appropriated and enjoyed yet simultaneously used as a means of explaining inequality. That culture explains inequality is important, as it allows for a "racism without racists" (Bonilla-Silva, 2006; Manning, Hartmann, \& Gerteis, 2015), insisting that it is not necessarily anything racial but rather cultural that explains (and justifies) inequalities.

In a conversation I had with Dafir, the Palestinian teacher at Al Amal, he distinguished between recent African immigrants and African Americans:

African Americans, a lot of them, they're disrespectful, and they don't work hard. Africans, they come here to work. But with African Americans, they don't have to work and so they don't. And when they see people who are working, they judge them. They don't know the value of a dollar.

I asked him where Arabs fell in his racial categorization and for him, the difference came down to immigration status, giving me a particular form of the segmented assimilation argument: "Arabs born and raised there, they're like Africans. Arabs born and raised here, they're no different from African Americans". What to make of Dafir's claims? There's obviously racism here, yet what does the racism accomplish? It allows Dafir to situate himself as a moral and racial arbiter, and to manifest a level of humility: after all, he is also an Arab "born and raised here". In this story, African Americans become the opposite of the (implicit) goal of assimilation, a process best exemplified by hard-working immigrants like Dafir's parents. The story manages to show loyalty, racial distinction, and humility all at once, all uttered in a seemingly colorblind rhetoric: after all, Dafir might say (though I did not ask him about it), if Africans and African Americans can be so different, surely this is not about race. As Dafir made clear above, he is not white, and neither does he want to be. Yet he also does not want to be like AfricanAmericans. His position of racial liminality allows him access to these racial hinges, able to make pronouncements that, in making them, situate his identity as racially liminal, neither white nor African-American yet able to talk expertly-at least in his mind-about both.

Jackson $(2005,2009)$ describes how immigrant Muslims situated themselves in opposition to African Americans from their first days in the United States, thereby maintaining white supremacy and anti-black racism even 
if they did not explicitly assimilate into the white majority (see also Beydoun, 2018, pp. 162-173; Prickett, 2015). Even 9/11, Jackson argues, has not really changed the situation (Jackson, 2005, p. 95). Importantly, a gradual shift towards an "American Islam" that is more than simply an accumulation of various ethnic forms does not solve this problem as it maintains the "ethnicity paradigm" Omi and Winant (2014) describe, making black simply one ethnicity among others and thereby occluding the differences between racist structures and ethnic distinctions. Yet such misrecognition can go even further. In Atiya Husain's (2017) study of white and black Muslims, an African-American man named Malik told her: "Muslims don't understand black folks". "But doesn't 'Muslims' include black folks?" the author asked. "You know what I mean", he responded, "It's the same for me". (Husain, 2017, p. 10). Husain's respondent shows how a colorblind ideological commitment to immigrant assimilation to America (if not necessarily whiteness) can occlude not only the black Muslim experience, but Muslim "black folks" themselves. It is through such occlusion that appropriation becomes possible. Yet more importantly for this article's argument, is through such occlusion that actors like Dafir are able to take advantage of this specific racial hinge, a capacity to "see past" race and in so doing situate their Muslim experience as the central concern of Islam in America and their racial experience as the way to understand how Islam is racialized. One of the many tragedies of Islam in America is how often scholars of American Islam themselves reify these occlusions of black Islam.

\section{Conclusion}

It is increasingly common to argue that Islam has become a "racialized" category in the United States, yet too often these accounts can emphasize a top-down process of government and media framing. Additionally, arguments about the "racialization" of Islam can de-emphasize the long-standing existence of black Muslims. In contrast, I have here suggested how immigrant Muslims' racial experiences are ambiguous, providing them with "racial hinges" through which they can negotiate their relationship to various racial and ethnic identities. These negotiations are situational, relational, and contingent; as $\mathrm{Hu}$ sain argues: "the meanings of Muslimness, blackness, and whiteness emerge through interaction with one another, specifically in the interaction of different identities (race and religion) within the same person" (Husain, 2017, p. 14).

Immigrant Muslims' "racial hinges" (Maghbouleh, 2017) allow some of them to maintain a kind of colorblind definition of true Islam, providing them with the capacity to strive for some of the benefits of whiteness, even if they do not necessarily gain them, and even if they do not necessarily claim to strive for whiteness itself, but rather its reification in the form of colorblindness. Immigrant Muslims can also appropriate black culture or seek greater relationships of solidarity with African Americans, especially African American Muslims.

While the term is still debated, "brown" is an increasingly common way of referring to immigrant Muslims' racial identity, and perhaps "brown solidarity and antiracism" is another racial strategy of action immigrant Muslims might take (Silva, 2010). Even black and white Muslims, in the moments they are recognized as Muslim, can become "brown" (Husain, 2017, p. 14). However, while theorists might describe Muslims as "brown", the degree to which most immigrant Muslims would agree to such a classification is a separate question, as is the degree to which black Americans would find the identity a helpful means of solidarity. Yet what makes a "brown" identity attractive to some is the degree to which it acknowledges immigrant Muslims' position in an American "racial order" (Emirbayer \& Desmond, 2015), giving up on both a colorblind ideology and an easy appropriation of black (and Latino) identity. In this sense, "brown identity" should not replace the problems of others' suffering (Jackson, 2009; Silva, 2016, p. 155) but rather seek to unite them together, paralleling Khabeer's (2016) account of "Muslim Cool" in which young people who identify themselves as black, brown, or something else can come together to create art, work for justice, and struggle to build an anti-racist ummah.

There remains much to understand in how the racialization of Islam works at the micro-level and how it relates to the experience of other racial identities. Future scholars might also examine the question of brown identity and the degree to which it is understood by immigrant Muslims themselves as a meaningful description. Further studies might also take up the question of how immigrant Muslims relate to other racial, ethnic, and religious groups, including East Asians, Latinos, non-Muslim South Asians, non-Muslim Middle Easterners, and subSaharan African immigrants, both Muslim and not. Doing so might provide a means of understanding how classifications of Islam function at the micro-level. These studies would also help develop Wilde's conception of "complex religion" as differences in race, ethnicity, and immigrant status potentially lead to significant differences in life outcomes and other measures of inequality (Wilde \& Tevington, 2017, pp. 7-8).

\section{Acknowledgments}

I am first deeply indebted to the community of Al Amal school for their kind welcome. I am very grateful for comments from Social Inclusion's anonymous reviewers and Melissa Wilde. Thank you also to Neda Maghbouleh for her own work and for a careful reading of an earlier draft. All errors are my own.

\section{Conflict of Interests}

The author declares no conflict of interests. 


\section{References}

Abdo, G. (2006). Mecca and Main Street. New York, NY: Oxford University Press.

Asad, T. (1993). Genealogies of religion. Baltimore, MD: Johns Hopkins University Press.

Bagby, I. (2012). The American mosque 2011. Washington, DC: Council on American Islamic Relations.

Bail, C. A. (2014). Terrified. Princeton, NJ: Princeton University Press.

Bayoumi, M. (2009). How does it feel to be a problem? New York, NY: Penguin.

Bayoumi, M. (2015). This Muslim American life. New York, NY: NYU Press.

Beydoun, K. A. (2018). American Islamophobia. Oakland, CA: University of California Press.

Bilici, M. (2012). Finding Mecca in America. Chicago, IL: University of Chicago Press.

Bonilla-Silva, E. (2006). Racism without racists. Lanham, MD: Rowman \& Littlefield.

Brubaker, R. (2013). Categories of analysis and categories of practice: A note on the study of Muslims in European countries of immigration. Ethnic and Racial Studies, 36(1), 1-8.

Brubaker, R. (2016). Trans. Princeton, NJ: Princeton University Press.

Brubaker, R., Loveman, M., \& Stamatov, P. (2004). Ethnicity as cognition. Theory and Society, 33(1), 31-64.

Cainkar, L. A. (2009). Homeland insecurity. New York, NY: Russell Sage Foundation.

Carr, J., \& Haynes, A. (2015). A clash of racializations: The policing of 'race'and of anti-Muslim racism in Ireland. Critical Sociology, 41(1), 21-40.

Du Bois, W. E. B. (2015). Souls of Black folk. New York, NY: Routledge.

Emerson, M. O., \& Smith, C. (2000). Divided by faith. New York, NY: Oxford University Press.

Emirbayer, M., \& Desmond, M. (2015). The racial order. Chicago, IL: University of Chicago Press.

Esposito, J. L. (2016). Islam: The straight path. New York, NY: Oxford University Press.

Fields, B. J., \& Fields, K. (2012). Racecraft. Brooklyn, NY: Verso Books.

Galonnier, J. (2015). The racialization of Muslims in France and the United States. Social Compass, 62(4), 570-583.

Gans, H. J. (1979). Symbolic ethnicity. Ethnic and Racial Studies, 2(1), 1-20.

Garner, S., \& Selod, S. (2015). The racialization of Muslims. Critical Sociology, 41(1), 9-19.

GhaneaBassiri, K. (2010). A history of Islam in America. New York, NY: Cambridge University Press.

Grewal, Z. (2013). Islam is a foreign country. New York, NY: New York University Press.

Guhin, J. (2014). Religion as site rather than religion as category. Sociology of Religion, 75(4), 579-593.

Huntington, S. P. (2004). Who are we? New York, NY: Simon and Schuster.
Husain, A. (2017). Moving beyond (and back to) the Black/White binary. Ethnic and Racial Studies, 1-18. https://doi.org/10.1080/01419870.2017.1410199

Hussain, A. (2010). (Re)presenting: Muslims on North American television. Contemporary Islam, 4(1), 55-75.

Hussain, A. (2016). Muslims and the making of America. Waco, TX: Baylor University Press.

Ibrahim, N. (2008). The origins of Muslim racialization in US law. UCLA Journal of Islamic \& Near Eastern Law, 7, 121-155.

Jackson, S. A. (2005). Islam and the Blackamerican. New York, NY: Oxford University Press.

Jackson, S. A. (2009). Islam and the problem of Black suffering. New York, NY: Oxford University Press.

Jamal, A. (2008). Civil liberties and the otherization of Arab and Muslim Americans. In A. Jamal \& N. Naber (Eds.), Race and Arab Americans before and after 9/11: From invisible citizens to visible subjects (pp. 114-130). Syracuse: Syracuse University Press.

Karim, J. (2008). American Muslim women. New York, NY: New York University Press.

Kashani, M. (2014). Seekers of sacred knowledge: Zaytuna College and the Education of American Muslims (Unpublished dissertation). University of Texas at Austin.

Khabeer, S. (2016). Muslim cool. New York, NY: New York University Press.

Kundnani, A. (2014). The Muslims are coming! Brooklyn, NY: Verso Books.

Love, E. (2017). Islamophobia and racism in America. New York, NY: New York University Press.

Lu, S., \& Fine, G. A. (1995). The presentation of ethnic authenticity. The Sociological Quarterly, 36(3), 535-553.

Maghbouleh, N. (2017). The limits of Whiteness. Stanford, CA: Stanford University Press.

Mahalingam, R. (2012). Misidentification, misembodiment and the paradox of being a model minority. Sikh Formations, 8(3), 299-304.

Mamdani, M. (2005). Good Muslim, Bad Muslim. New York, NY: Doubleday.

Manning, A., Hartmann, D., \& Gerteis, J. (2015). Colorblindness in black and white. Sociology of Race and Ethnicity, 1(4), 532-546.

Marzouki, N. (2017). Islam: An American religion. New York, NY: Columbia University Press.

Masuzawa, T. (2005). The invention of world religions. Chicago, IL: University of Chicago Press.

Morning, A. (2001). The racial self-identification of South Asians in the United States. Journal of Ethnic and Migration Studies, 27(1), 61-79.

Morning, A. (2008). Ethnic classification in global perspective. Population Research and Policy Review, 27(2), 239-272.

Morning, A. (2009). Toward a sociology of racial conceptualization for the 21st century. Social Forces, 87(3), 1167-1192. 
Motyl, K. (2011). No longer a promised land: The Arab and Muslim experience in the US after 9/11. REAL Yearbook of Research in English and American Literature, 27, 217-235.

Naber, N. (2005). Muslim first, Arab second. The Muslim World, 95(4), 479-495.

Naber, N. (2012). Arab America. New York, NY: New York University Press.

O’Brien, J. (2017). Keeping it halal. Princeton, NJ: Princeton University Press.

Omi, M., \& Winant, H. (2014). Racial formation in the United States. New York, NY: Routledge.

Peek, L. (2011). Behind the backlash: Muslim Americans after 9/11. Philadelphia, PA: Temple University Press.

Pew. (2017). U.S. Muslims concerned about their place in society, but continue to believe in the American dream: Findings from the pew research center's 2017 survey of U.S. Muslims. Pew Research Center. Retrieved from www.pewforum.org/2017/07/26/ findings-from-pew-research-centers-2017-survey-ofus-muslims

Portes, A., Fernandez-Kelly, P., \& Haller, W. (2005). Segmented assimilation on the ground. Ethnic and Racial Studies, 28(6), 1000-1040.

Portes, A., \& Rumbaut, R. G. (2016). Immigrant America. Berkeley, CA: University of California Press.

Prickett, P. J. (2015). Negotiating gendered religious space: The particularities of patriarchy in an African American mosque. Gender \& Society, 29(1), 51-72.

Read, J. (2008). Discrimination and identity formation in a post-9/11 era. In A. Jamal \& N. Naber (Eds.), Race and Arab Americans before and after 9/11: From invisible citizens to visible subjects (pp. 305-317). Syracuse: Syracuse University Press.

Rodriquez, J. (2006). Color-blind ideology and the cultural appropriation of hip-hop. Journal of Contemporary Ethnography, 35(6), 645-668.

Roth, W. (2005). The end of the one-drop rule? Labeling of multiracial children in Black intermarriages. Sociological Forum, 20(1), 35-67.

Roth, W. (2012). Race migrations. Stanford, CA: Stanford University Press.

Rouse, C. (2004). Engaged surrender: African American women and Islam. Berkeley, CA: University of California Press.

Saeed, A. (2007). Media, racism and Islamophobia. Sociology Compass, 1(2), 443-462.
Sanchez, G., \& Romero, M. (2010). Critical race theory in the US sociology of immigration. Sociology Compass, 4(9), 779-788.

Saperstein, A., \& Penner, A. M. (2012). Racial fluidity and inequality in the United States. American Journal of Sociology, 118(3), 676-727.

Selod, S. (2015). Citizenship denied: The racialization of Muslim American men and women post-9/11. Critical Sociology, 41(1), 77-95.

Selod, S., \& Embrick, D. G. (2013). Racialization and Muslims. Sociology Compass, 7(8), 644-655.

Silva, K. (2010). Brown: From identity to identification. Cultural Studies, 24(2), 167-182.

Silva, K. (2016). Brown threat. Minneapolis, MN: University of Minnesota Press.

Swidler, A. (1986). Culture in action: Symbols and strategies. American Sociological Review, 51(2), 273-286.

Tourage, M. (2013). Performing belief and reviving Islam: Prominent (White male) converts in Muslim revival conventions. Performing Islam, 1(2), 207-226.

Warikoo, N. K. (2011). Balancing acts: Youth culture in the global city. Berkeley, CA: University of California Press.

Warner, R. S. (2007). The role of religion in the process of segmented assimilation. The Annals of the American Academy of Political and Social Science, 612(1), 100-115.

Waters, M. (2001). Black identities. Cambridge: Harvard University Press.

Wilde, M. (2017). Complex religion: Interrogating assumptions of independence in the study of religion. Sociology of Religion, srx047, https://doi.org/ 10.1093/socrel/srx047

Wilde, M., \& Glassman, L. (2016). How complex religion can improve our understanding of American politics. Annual Review of Sociology, 42, 407-425.

Wilde, M., \& Tevington, P. (2017). Complex religion: Toward a better understanding of the ways in which religion intersects with inequality. Emerging Trends in the Social and Behavioral Sciences, https://doi.org/ 10.1002/9781118900772.etrds0440

Zhou, M. (1997). Segmented assimilation. International Migration Review, 31(4), 975-1008.

Zopf, B. J. (2017). A different kind of brown: Arabs and Middle Easterners as anti-american Muslims. Sociology of Race and Ethnicity, 4(2), 178-191.

\section{About the Author}

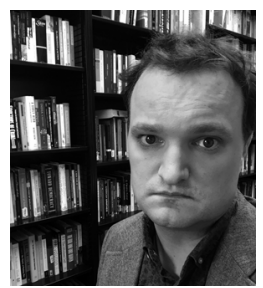

Jeffrey Guhin is an Assistant Professor of Sociology at UCLA. His research interests include education, religion, culture, and theory. His next project is a comparative study of moral correction in Catholic, Muslim and secular 4th grade classrooms. 